\title{
Skinny blues: \\ Karen Carpenter, anorexia nervosa and popular music
}

\author{
George McKay
}

\begin{abstract}
We might locate that colloquial inauguration of anorexia on a Las Vegas nightclub stage in the fall of 1975, when the popular musician Karen Carpenter collapsed while singing 'Top of the world'; or on the morning of 5 February 1983, when news [broke] of Carpenter's death from a 'starvation diet' .... [I]n the 1970s and 1980s [anorexia] ... became a vernacular, an everyday word, an idiom.

Patrick Anderson, So Much Wasted (2010, 32)
\end{abstract}

The words come out of yr mouth but yr eyes say other things, 'Help me, please, I'm lost in my own passive resistance, something went wrong' .... Did anyone ever ask you that question-what's it like being a girl in music?

$$
\text { Kim Gordon, 'Open letter to Karen’ (n.d.) }
$$

This article discusses an extraordinary body (Thomson 1997) in popular music, that belonging to the person with anorexia which is also usually a gendered body-female-and that of the singer or frontperson. I explore the relation between the anorexic body and popular music, which is more than simply looking at constructions of anorexia in pop. It involves contextually thinking about the (medical) history and the critical reception and representation, the place of anorexia across the creative industries more widely, and a particular moment when pop played a role in the public awareness of anorexia. Following such context I will look in more detail at a small number of popular music artists who had experience of anorexia, their stage and media presentations (of it), and how they did or apparently did not explore their experience of it in their own work and public appearances. This close discussion is framed within thinking about the popular music industry's capacity for carelessness, its schedule of pressure and practice of destruction on its own stars, particularly in this instance its female artists. This is an article about a condition and an industry. At its heart is the American singer and drummer Karen Carpenter (1950-1983), a major international pop star in the 1970s, in the Carpenters duo with her brother Richard; the other figures I introduce are Scottish child pop star Lena Zavaroni (1963-1999), and the Welsh rock lyricist, stylist and erstwhile guitarist of the Manic Street Preachers, Richey Edwards (1967-1995 missing/2008 officially presumed dead).

I draw on and seek to develop the work undertaken by the likes of $\mathrm{Su}$ Holmes on what she has recently termed 'star or celebrity anorexia' (Holmes 2015, 815), and Paula Saukko on how female celebrity images circulate discourses on anorexia (2006). But my focus is on music rather than media, with a critical interest in ways in which the practices and expectations of the music 
industry set a conformist template of corporeality, particularly for its female stars. Media discourses are introduced for material about the presentation and representation of the anorexic body (for example, from reviews and interviews in the contemporary music press, as well as televised performances and music videos). The specific musical considerations include discussion of the choice of instrumentation, the (sound of the) singing voice, and the analysis of lyricswith a theoretical approach informed by ways of thinking about the musically performative body from disability cultural studies (Thomson 1997, Lubet 2011, McKay 2013). As noted, these musical questions are centred on Karen Carpenter, both to reflect on her experiences of anorexia and to contribute further to the critical interrogation of how pop operates, especially for its female artists. Her lack of public utterance on her anorexia, right up to her death, is understandable, given her lonely and vulnerable position as the global star first and most associated with it. But it is also problematic, not least since it leaves key male figures around her to shape and control her narrative-regular Carpenters lyricist John Bettis whose songs constituted what biographer Ray Coleman calls the 'sound tracks of her personal life' (Coleman 1994, 148), and brother Richard as Carpenters spokesperson and protector of the legacy, in particular. The article concludes with observations about the place of popular music in seeking to capture experiences of anorexia and related eating disorders in younger people today, and the balancing act between popular song as trigger, as therapy, and as a certain form of authentic experience and expression.

There is remarkably little sustained writing on the culture of Karen Carpenter (Jarman-Ivens 2007, Lott 2008, Jarman-Ivens 2011, Morris 2013, Smith 2014), bearing in mind her major international success in pop, her musical innovation as female drummer-lead singer, and that she was the figure first and most associated in the public's mind with what they thought of in the mid-1970s as the new condition of anorexia nervosa. ${ }^{1}$ The Carpenters were and are one of the world's best-selling music acts, with claimed record sales of 100 million and certified sales of 45.9 million, from an active career from 1969 to 1983, when Karen died, as well as compilations, re-masterings and releases of previously unreleased material since then ('List of best-selling music artists' 2017). Yet my literature search on Carpenter located significantly more scholarly writing about, for example, Todd Haynes and Cynthia Schneider's short 1987 Karen/Barbie film Superstar: The Karen Carpenter Story than has ever been written on the music of Carpenter herself, her extraordinarily successful portfolio of recorded and live playing and singing, her media (television) career, her life and death. Although there are at least two popular biographies today (Coleman 1994, Schmidt 2010), it remains the case that Karen and Richard Carpenter have been ill-served by popular music and cultural studies scholars, have not been deemed worthy of 'featur[ing] heavily in popular musicology', as Freya Jarman-Ivens puts it (2011, 63) - just 'too popular to be impressive' to most of us (Morris 2013, 2). It seems AOR and MOR, categories between which we might place much of the Carpenters repertoire, still do not excite the scholars sufficiently, and, more broadly, female pop artists especially, as Jarman-Ivens notes, still remain under-researched.

\footnotetext{
${ }^{1}$ As Helen Malson shows in The Thin Woman, the medical discourse around the condition originates a century earlier, in the 1870s (1998).
} 
CAPTION Fig. 1. 'Young America at its very best.' Karen and Richard Carpenter at the White House with President Nixon, 1 August 1972

The Carpenters were never cool, even when Sonic Youth et al tried to reclaim them in the 1990s (Sonic Youth 1990, Various artists 1994). Back in the late 1960s and early 1970s theirs was a deep music, of multi-layered vocal harmonies and overdubbed keyboards, but it sounded empty. It seemed to be less about expression than a kind of repression. It was cold not soul, and you couldn't really dance to it. An extraordinary contralto pop voice, with wonderfully resonant low notes ('the money's in the basement', Karen used to say: quoted in Coleman 1994, 237), always felt disembodied. Regular guests at the White House, in 1973 President Nixon presented the Carpenters to West German Chancellor Willy Brandt as 'one of the finest young groups in America', and 'young America at its very best' (quoted in Schmidt 2010, 101) (Figure 1). Politically theirs was a public musical culture of conservatism; it was wholesome and contained, and in seemingly stark contrast to the sonic experiments and gestures of the counterculture-variously a 'soft rock music ... embod[ying] the US family values of the 1970s' (Saukko 2006, 153, 152) or the essential soundtrack to 'turn-of-the-seventies Southern California unfreedom' (Lott 2008, 224). They 'never lacked disparagers', notes Mitchell Morris $(2013,118)$. Rock critic Lester Bangs had reviewed a concert for Rolling Stone in 1971 and concluded 'band and audience ... gave me the creeps' - the review was entitled 'The Carpenters and the creeps' $(1971,21)$. Eric Lott describes the Carpenters music as 'a brand of Los Angeles vernacular sentimental poetic production for the airwaves', with its 'smooth, reified, even fetishistic sheen.' And yet, he continues, '[t] he apparently unbroken surface of this industrially manufactured sound ... is in fact riven by longing, constriction, and discomfort' $(2008,219)$.

To turn from the industry and music to the condition and health history, there is an identifiable historical public epidemiology: preceded in the mass media, the social imaginary and the fearscape by polio (Shell 2005, McKay 2009) in the 1950s or thalidomide (Vargesson 2015) in the late 1950s and early 1960s, 'anorexia nervosa began to be "popularized" in the 1970s, to be obscured only by AIDS' in the 1980s (Brumberg 2000,13). While profoundly visible through the shock of the thin, its public symptom and presentation or display readily identifiable today, the eating disorder of anorexia nervosa is complicated. It may be that it is a condition combining elements of cognitive and physical impairment, a mental health issue leading to or presenting in a diminished corporeality. It may be that it is instead or as well a social and cultural phenomenon, or rather one understood as originating at least in part in the socio-cultural. Generally, the first of these is from a medical perspective, the second from a feminist one. Patrick Anderson has articulated 'the critical dialectic' within approaches to anorexia, between 'the complicated nosology of anorexia as a disease' and 'anorexia as a symptom of ... cultural power' and gendered body expectations (2010, 33; emphases original). Anorexia is complex and can be contradictory: Helen Malson and Jane Ussher have observed that the thin or "anorexic" body may be discursively construed in a multiplicity of often conflicting ways,' and one key example they offer of this is that it may signify 
both self-production (of idealised body or identity) and self-destruction (symbolically and physically) $(1997,49)$. A clinical definition from Magill's Medical Guide informs us that 'anorexia nervosa is an eating disorder characterized by a body weight at or below 85 per cent of normal, an intense fear of weight gain that leads to restrictive eating to the point of self-starvation, and a distorted perception of one's body weight and the seriousness of the effects of the disorders' (Pawlowski and DeAngelo 2016). Yet, even though this is a clinical description, it goes on to point out that anorexia is 'a multi-faceted problem that has physical, genetic, emotional, and cultural components.' More specifically, anorexia 'gained the attention of medical professionals during the 1960s and beyond as a result of the media's obsession with thinness. The media are prime contributors to this trend' (Pawlowski and DeAngelo 2016; emphases added).

In the cultural context, it has been recognised that some creative practices and industries have had a greater tendency towards anorexia than others. David Garner and Paul Garfinkel's early study of 'socio-cultural factors' found that trainee professional dancers and student fashion models were susceptible; this contrasted with, for instance, students in music colleges and conservatories who, although also (like the dancers) having to undergo 'demanding and competitive training', were 'not required to maintain a thin body shape for their careers' $(1980,648)$. Thus, '[a]norexia nervosa and excessive dieting concerns were overrepresented in the dance and modelling students' (Garner and Garfinkel $1980,647)$, and with dance-especially at ballet school-many of the students developed anorexia 'while actively studying' (652). Further, ' $28 \%$ of the professionally oriented dance sample were amenorrhoeic' (653). It may be that the cultural analysis of eating disorders like anorexia has replicated the position of certain creative industries: a meta-analysis of studies undertaken on the impact of idealised thin bodies in the media found that over $80 \%$ (21 of 25 discussed) 'employed fashion magazine images (still photographs) as experimental stimuli' (see Tiggemann and Slater 2004, 49; emphasis added). Work on 'the impact of thin ideals' in pop music videos on young female viewers found, perhaps unsurprisingly, that 'brief exposure to music videos containing thin and attractive images of women led to increases in body dissatisfaction' among the female viewers (Tiggemann and Slater 2004, 49, 55). So: studies of both creative practice and media representation have affirmed a cultural connection. It is important to acknowledge that this has been problematised by recent critical feminist scholars wary of over-emphasising what Maree Burns has termed 'the inscriptive power of cultural images of thinness,' which may 'render persons [with experience of eating disorders] as passive and docile rather than (also as) engaging with, resisting and potentially transforming the discourses embedded within those images' (Burns 2009, 124-125). In media studies more generally readings of fans as 'global prosumers' of accelerated and 'YouTubeificated' audiovisual media also problematise straightforward passive impact and influence relations (Vernallis 2013, 14-15).

How does anorexia resonate in pop? Arguably popular music scholars may recognise in 'the combination of ambition to achieve and dark drive to selfdestruct that is characteristic of eating disorders' (Saukko 2006, 162; emphasis added) a familiar personality profile from their own cultural realm; in my own 
work I have termed this an aspect of pop's 'destructive economy' (McKay 2013). The role of the industry is identified by some other scholars as bearing responsibility. Eric Lott, for, example, describes how Karen Carpenter '[i]nternaliz[ed] the [music] business's murderous pressure on the female image' $(2008,230)$. Holmes point out that Lena Zavaroni's 'anorexia was often explained in terms of the normative script of the "damaged" child star in which fame itself led to her demise' (2015, 815; emphasis original). More widely, a trawl through online media sources such as celebrity news, fans' websites, and listicles, reveals many pop figures presenting and repeating a familiar narrative. A recent feature on celebrity site Rant Hollywood, for example, contains a list of ' 15 musicians who have suffered from eating disorders', with a photograph and a single sentence diagnosis or explanation for each. It confirms the place of eating disorders in media and public discourse of (primarily female) pop. The musicians include Lady Gaga, Alanis Morissette, Victoria Beckham of the Spice Girls, Ke\$ha, and Diana Ross, and many are quoted as explaining their disorder via the industry: anorexia 'the result of the anxiety caused by the demands of [producer] Berry Gordy' (Ross), 'part of my job was to be as skinny as possible and, to make that happen, I had been abusing my body' (Ke\$ha), 'suffered between the ages of 14 to 18 while trying to break into the music industry' (Morissette), 'under a great amount of pressure to lose weight and stay fit to maintain her pop star image' (Beckham) (see Rose 2015). To answer Kim's question to Karen (in one of my epigraphs): this is what it's like being a girl in music. (For other ways in which 'the idea of "girl" can belittle and empower' in popular music see Warwick and Adrian 2016: 2; emphasis added.)

CAPTION Fig. 2. 'To be as thin as a mic stand is ... cool.' Richey Edwards, 1994, from Manic Street Preachers 'Revol' video, single release from The Holy Bible album

Sometimes it's a boy. Intriguingly, in Paula Saukko's view to be a thin woman 'articulate[s] a contradictory desire to be both ultra-feminine and masculine' $(2006,154)$ - arguably this might be thought less of a contradiction in rock and pop than in other spheres. In pop to be as thin as a mic stand is a cool achievement, while to be feminine and masculine at the same time is frequently another (see Figure 2). As it progressed, Richey Edwards's weight loss was becoming increasingly both noticeable and displayed by him, part of his preparation for Manics stage shows even, as bassist Nicky Wire later recalled: often 'anorexics try to cover up their condition with baggy clothes.... But on the first day of the British tour, Richey walks in and he's wearing the tightest pair of girls' leggings I've ever seen in my life. He still wanted the rest of the world to know he was fucked up' (Wire, quoted in Power 2010, n.p.). And fans generally prefer their rock survivors to be skinny, like Mick or Keith; if weighty or fat, especially where that contrasts with the youthful vigour of their pop prime, they are figures of ridicule, embarrassment, or at best pity. I think of late period Elvis, cruelly described by Greil Marcus in full American mythographic mode as the 'white whale' $(1991,3)$. The spectacular public meltdown in 2007 of another transformed popster, Britney Spears, was, as Amy Erdman Farrell puts it in Fat Shame, a celebrity downfall story covered 'in excruciating detail ... largely told through a narrative about her fat body' (Farrell 2011, 121). 


\section{Karen, on top of the world, dealing with 'the pressures of the business'}

Karen met the culture industry on its own terms, and lost.

Eric Lott, 'Perfect is dead' $(2008,230)$

According to Patrick Anderson, then, Karen collapsed in Las Vegas in 1975 while singing 'Top of the world', an event which began to open up to public consciousness the condition of anorexia nervosa. An upbeat country-tinged love song co-written by brother Richard Carpenter (music) and regular Carpenters lyricist John Bettis, 'Top of the world' had been a no. 1 single in the United States in 1973, and was a highlight of the Carpenters' live show. The opening line is 'Such a feeling coming over me' (Carpenters 1972) -if not dissociated, is this what you sing before your body collapses on stage? Ray Coleman's biography of the band, which, although authorised by Richard with some clunking editorial interventions, does focus on both his and her health and addictions during their years of fame, puts the sudden end of the 1975 US tour and the cancellation of the Europe and Japan tours to follow slightly less dramatically than Anderson (there is no onstage collapse, for example). Yet Coleman too captures the concern about and shock of Karen Carpenter's health.

[S] he was in deep physical trouble, down to around eighty pounds, ... yet astounding everyone with her perfect vocal performance. But there was no kidding between the shows. In Las Vegas she could hardly wait to leave the stage and reach ... her dressing room, where she lay, or slept, until the second show. (Coleman 1994, 186)

(Schmidt has her weight at $91 \mathrm{lbs}$ in September 1975, and writes that 'she made it through the Vegas shows without a major incident': 2010,127, 144.) By now, at the band's peak in popularity, '[t]here was often a collective gasp from the audience when Karen would take the stage' and they saw her body (Schmidt $2010,137)$. An otherwise favourable review in Variety of the 1975 Vegas shows noted that 'she is terribly thin, almost a wraith'-and, in an indication of the lack of awareness of the times, concluded with a suggested solution that was both thoughtless and unhelpful: she 'should be gowned more becomingly' (Anon $1975,135)$. Despite the rearranged and reduced schedule within a couple of years she would go on to have what she casually described as 'a ministroke' (quoted in Coleman 1994, 232), struggling with her eating disorder and complications resulting from it. She died in 1983 at the age of 32, following a heart attack, or, as her death certificate put it, 'emetine cardiotoxicity due to or as a consequence of anorexia nervosa'; her heart muscles were apparently atrophied by recent regular use of the well-known emetic ipecac syrup (Schmidt 2010, 283).

Nine months after her death Richard was plugging a new album by the Carpenters, of unreleased out-takes and songs from her final recording session he had subsequently arranged and produced in the studio. On ABC's Good Morning America he was probed on the role of the industry in his sister's premature death, saying 
It's easy to point a finger at the pressures of the business, but Karen adored her career, and the pressures-and so do I-so I really, really don't think it was that at all. (Carpenter 1983)

Shortly afterwards, in the same interview, he points precisely to 'her active schedule' as in fact being a key contributory factor in her cardiac arrest. We should remember that the Carpenters had been a live act as well as a studio phenomenon. Schmidt tells us that between 1971 and 1973 they performed 150175 concerts per year around the world, frequently in the form of punishing sixweek stints of one-nighters (Schmidt 2010, 121). An album would take four to five months to produce, and then there were extensive television, radio and other media duties. It was a relentless schedule, a 'ridiculous schedule' in Karen's own view, as articulated in late 1975 when quizzed about her health and the postponed tours (quoted in Coleman 1975, 155).

She occasionally pointed to ways in which, even early on, the lifestyle of flux and semi-structure that came with live playing and extensive touring disrupted the simple daily routine of food and meals-or perhaps she was already thinking about justifying a new relationship with eating. As early as 1973 she said: 'When you're on the road it's kind of hard to eat. Period. On top of that, it's really hard to eat well. We don't like to eat before a show because I can't stand singing with a full stomach' (quoted in Schmidt 2010, 127; emphasis original). The reasons she offers here for not eating (well, or at all) are linked with her musical life. I am uncertain whether she could not sing 'with a full stomach' for technical reasons to do with breathing, projection, comfort, or because, as she goes on to say in the same interview, 'if you eat heavy you're going to be a balloon' - that is, she already thought she would look fat on stage if she ate before a show. We can sense here how Karen, like other '[f]emale stars and celebrities[,] live[d] under a constant media spotlight of surveillance which in turn demand[ed] a prescriptive regime of self-maintenance' (Holmes 2015, 815). There was also stark gendering of the touring and live experience. In a 1981 BBC radio interview, Karen looked back on the effects of being surrounded by exclusively male band members, which could be oppressive and isolating:

At one point, there were thirty-two of us on the road. It's a big bunch. You tend to travel in the same circles with the same people, meet the same people, and hang out with the same people.... Being the only girl, outside of my hairdresser, it's not easy having thirty brothers on the road. Everybody, including management, is extremely protective.... You really don't meet anybody. (quoted in Schmidt 2010, 109)

As with some of the songs, Karen's words can resonate subtextually. If your own brother and co-star has a powerful reputation as a controlling presence, how magnified is the experience of gendered control when it feels like there are 'thirty brothers on the road'? Management could indeed be 'extremely protective' - their practice extended effectively to trying to control her love life, by secretly paying off boyfriends they thought unsuitable (Coleman 1994, 199201). Thus they sought to protect their investment in their superstar-there was 
a common view that the success of A\&M Records was largely built on the Carpenters's huge sales, after all, sales which also subsidised the more rock and experimental end of the company roster (Coleman 1994, 96).

Touring was unsustainable at such intense levels, and, overnight, midtour, in late 1978 the Carpenters suddenly stopped playing live and disbanded their long-term backing group. Karen's life would now feature a string of therapists and medical interventions, hospitalisation, emergency hyperalimentation to increase her weight, her extreme use of laxatives and later emetics, alongside a fairytale marriage in 1980 and its swift failure. Su Holmes writes of 'the media spectacle of [Lena Zavaroni's] anorexia' $(2015,815)$, which differs starkly from Karen Carpenter's reticence, denial, and silence about her condition within the media. An excruciating out-take exists of an October 1981 BBC interview with the Carpenters, Karen visibly frail, painfully thin, clearly illthough still smiling, quite feisty, and capable of cracking jokes. She is probed initially by interviewer Sue Lawley about the duo's lengthy absence, and then about Karen's health. 'I was just pooped', she explains, 'when you've been on the road for all those years without stopping...' She denies having (had) anorexia nervosa when the point is put to her fairly bluntly by Lawley-soon Richard interrupts off-camera and says 'I don't really feel we should be talking about the weight loss, maybe it's better to take a pass', and the subject is dropped for the broadcast interview (Nationwide 1981). The out-take shows both her self-denial and his agency in terms of media representation, each in stark contrast to the evidence of her body before the camera.

There was always the career: recording a solo album in 1979 and 1980 that was not released by the record company, a relative return to form with Richard on 1981's Made in America, and regular television specials in lieu of live appearances. Saukko understands the recording project in particular within a frame of personal autonomy and health.

Carpenter's attempt to solo with more mature or daring songs (three of the songs were disco) symbolized her desire to become an independent person and to break free of her oppressive familial and professional environment, which were hinted to have contributed to her anorexia. $(2006,161)^{2}$

\footnotetext{
2 The solo album, entitled Karen Carpenter, was finally released in 1996, 13 years after her death. The sleeve notes by producer Phil Ramone inform us that the tracks were as mixed with Karen in the studio, except for the 'unmixed' bonus track , the final one on the album. Her version of 'Last one singin' the blues' (Carpenter 1996) is a fine and resonant recording, made more interesting and one could say moving even because the intro and middle eight still feature her spoken instructions to the band: 'Just a cinch slower, Lib' (to drummer Liberty DeVitto), 'Don't forget the break'. In the studio, with a producer who was not her brother, and a different band, recording her solo album, she is, for a while, in control. That Richard and the A\&M Records senior executives should absolutely veto its release in 1980 is certainly a powerful statement of male disregard and reassertion of gendered authority.
} 
Meanwhile Richard was in his own showbiz success hell for a while: addicted to Quaaludes (prescription sedatives), he could not sign an autograph on tour let alone play piano because of physical tremors, and his voice was slurred, which meant harmonies might suffer (Schmidt 2010, 184). From President Nixon's 'young America at its very best', the Carpenters were rapidly heading into a dual pop cycle of therapy and rehab, to the accompaniment of postponed tours, and even rumours of a split-dysfunction surely magnified by the 'discourse of control' and 'perfectionist tendencies' which brother and sister shared, in studio and on stage (Jarman-Ivens 2011, 71).

\section{Chick drummer, chick singer}

I want to look more closely at two further aspects of Karen Carpenter's musical career which throw light both on her life and health, as her anorexia progressed, and on ways in which popular music practices and conventions functioned to control or accommodate her extraordinary body. These are: her identity as drummer, and the ways in which that changed; her singing voice and sung lyrics, and the complexities of how these may have repressed or communicated her condition.

First, let us remember that, before she was the lead singer, Karen Carpenter was the drummer. Further: on the Carpenters's first album, originally released in 1969 as Offering, she also plays bass guitar on two songs, so we should say that at this time she was a multi-instrumentalist. As a student at California State University in the 1960s 'Karen was the only female drummer on the campus', and, more remarkably still, even with 'the pop revolution in full swing ... a female drummer who sang was rare indeed' (Coleman 1994, 56, 54; emphasis added). The sense of rarity and surprise seems to endure-even Angela Smith, in her recent book Women Drummers, introducing her subjects via a list of names, adds a qualification and exclamation after the name of the first: 'the emphasis is on women who ... have been at the top of their class in popular and contemporary jazz, country, blues, and rock-women such as Karen Carpenter-yes, Karen Carpenter!' (Smith 2014, xvii-xviii). She was technically good, with a jazzy touch-good enough for Richard to foreground the drumming in some of his arrangements for Offering: 'Your wonderful parade' ends with a drum solo; 'All I can do' is in 5/4 time, with a driving jazz feel. I do not want to overstate the case, but there is also in the tight and slightly experimental jazz arrangements by the embryonic Carpenters in demo recordings from the mid1960s a glimpse of a different drumming, from the then teenage girl. A decade later, in Playboy magazine's 1975 annual readers' poll Karen topped the Best Rock Drummer of the Year category, above Led Zeppelin's John Bonham in second (he was not pleased) (Smith 2014,121). It should also be noted that she featured on music trade press advertisements, mainly alongside male drummers, for Zildjian cymbals in 1971 and Ludwig drums the following year-so there was a degree of acceptance and recognition from the wider industry of her achievements as a drummer. 
Yet there was pressure on the drummer-singer to step out from behind the kit, and from the back to the front of the stage. As Lott explains, 'she was implored by Richard to abandon the drums, crimping her musicianship and putting her out front, where her paralyzing self-consciousness was only redoubled' (2008, 231). Not only Richard. Reviewers wrote pieces with titles like 'Bring Karen from behind those drums': 'Why stick a lovely girl with a tremendous voice behind a set of traps ... when by rights she should be out front moving to the music while she sings?' (James Bresette, 1971, quoted in Schmidt $2010,84)$. An increase in bodily visibility onstage confirmed the positioning and reinstatement of a conventional female role, even though this is explicitly not what she wanted. (On the topic of her drumming Karen was regularly vocal, and happy to offer a gender perspective. At high school, where '[a]ll I ever heard was "girls don't play drums,"' she had quickly joined an all-girl band, after all:

Schmidt 2010, 25, 27.) We should acknowledge that this was a reinstatement of a conventional singer's role too: not many long-term successful pop bands have featured a lead singer who is also the drummer, whether male or female. ${ }^{3}$ In terms of the relation between her instrument-'the drums made her barely visible during performances' (Smith 2014, 119) —and her perception of her own body, it was commonly felt by the men around her that Karen framed this in the context of weight. An early boyfriend explained her fear that 'when she ate her weight went to her hips, so she wouldn't eat.... She was always worried about the hips, and that's one of the reasons she wanted to stay at the drums' (quoted in Schmidt 2010, 120). Her then manager, Sherwin Bash, recalled her as 'a chubby young lady who could hide some of that chubbiness behind all these drums.' Altogether more accurately (she was not 'chubby'), Bash went on to say that 'She was kind of a tomboy, and the drums were traditionally a male instrument. She was kind of asserting herself in a certain way' (quoted in Schmidt 2010, 84). So, at the same time, the drums were indeed a mode of gender assertion for her, as a successful and rising young woman during the women's liberation movement. As she herself put it in 1970: 'A lot of people think that since I'm the lead singer I should be fronting the group. I disagree because I think we've got enough chick singers fronting groups. I think as long as I can play [the drums], I want to play' (quoted in Schmidt 2010, 84).

But what happened was that Richard sang less, she drummed less, and she became the 'chick singer fronting [the] group,' conforming to industry expectations, and piling pressure for years to come on her self-image onstage before an audience, alone under the spot. If the 'anorexic body is a body that appears to disappear', then, 'paradoxically, this disappearing body also becomes more visible' (Malson and Ussher 1997, 51; emphasis original). As Karen the singer became more visible in shows, so what Lott calls her 'gruesome disappearing act' began in earnest and was finessed $(2008,227)$. Karen seemed to sense that the move to front of stage was a source of damage to her. In the long and surprisingly candid Melody Maker interview a few months after her

\footnotetext{
${ }^{3}$ Well-known male drummer-lead singers include Mickey Dolenz, Robert Wyatt, Don Henley, Phil Collins; pop bands like the Dave Clark 5 and Paper Lace. Female, apart from Karen? Very few. Sheila E. (with Prince) is one. Karen really was-indeed, is-a striking innovator in this regard.
} 
1975 health crisis she told Ray Coleman: 'it hurt me that I had to get up and be up front. I didn't want to give up my playing. Singing was an accident. Singing seriously came long after the drums' (quoted in Coleman 1975, 148; emphasis added). (In later years there would be talk of Karen guesting on drums on, of all things, her friend Olivia Newton-John's Physical tour in 1982, but by then she was 'far too weak': Schmidt 2010, 271.) Let us be clear: her striking early innovation as a successful female drummer-lead singer has rarely if ever been repeated in pop. What we can think of as her new way of combining playing and singing offered a different look on stage, which could of course be exploited as a sort of pop gimmick but was also an inspiring example for especially young female viewers (pace Kim Gordon and Sheila E., for a start). Karen recognised and revelled in her dual musical role, which was removed from her against her will by the men around her (brother, management). Arguably, she did become a bigger star with more hit songs and greater record sales, but her musical innovation, creativity, expression and contribution were diminished.

Second, as for the singing voice and the very words being sung-some written especially for her, usually by John Bettis, others chosen for her by Richard-these too are complex, even conflicting in the search for meaning and self-understanding. Trying to make sense of Karen's voice has us reaching for contradiction or antithesis. After all, she did tell us that 'there's two sides, two interpretations / A laugh is a cry, hello means goodbye' (Carpenters 1977a). Her voice 'is the ultimate for me', wrote one early critic, '[b]oth more bland ... and more resonant than any other' (Smucker 1975, 86). In Lott's view, her 'voice is unmatched in its ability to summon a languid melancholy that is somehow at the same time evacuated of personality' $(2008,221)$. For Jarman-Ivens, the "natural" voice of Karen is played off against the "synthetic"' technologised sections of Richard's productions $(2011,92)$. For Morris, 'the songs seem to embody a split between a virtuosically smooth [musical] exterior ... and an abject interiority just under the sheen of that voice' $(2013,120)$. Elsewhere I have made an effort to locate what disabled singer Neil Young has called popular music's 'weird voices' within disability discourse, in order to further understand the meanings of the sounds of such voices and their relation to their producing bodies (McKay 2013). This has led me to offering the theorisation of mal canto for such efforts-rather than bel canto - and I would extent the argument here to posit that, in popular music at least, mal canto has frequently, generally even, been male canto, a gendered vocal practice of disability that privileges masculine crip experience.

But with Karen Carpenter the issue is not one of imperfection, paralleling and extending in mal canto the damaged body via damaged voice. Rather, the issue in fact is vocal perfection. Karen seemed to be striving for what she thought of as versions of perfection in voice and in body alike, could we say that? I think this is the significance of Jarman-Ivens's point about her voice, drawing on Roland Barthes, when she writes of 'the grain-disciplining, antibodily soundscape offered by the Carpenters' $(2011,86)$. Even when Richard decides to leave evidence of the body in the songs, a present corporeality on some of her vocal recordings in the form of the sound of her inhalations not edited out, these 'deep breaths' preceding lines are read as adding 'a special, unexpected dimension' (Coleman 1994, 125)—only in an 'antibodily soundscape' such as 
that of the Carpenters could the warmth or human sound of natural breathing be thought so surprising (see also Jarman-Ivens 2007). Yet, through her closeness to the mic, in the studio especially, 'it is possible to hear fine-grained articulations' in her singing voice. Such a recording technique of 'sonic close-up' may produce an 'infectious' or attractive intimacy, which, taken together with her timbral qualities and the low register, make for an ideal 'evocation of melancholy', especially when we pay attention to the words she also singing (Morris 2013, 134). For Morris, listening to Karen's voice is a compelling experience of sentimentality:

When the power of [her] register is married to partial shadings of vowels and consonants and constant decorative departures by scoop and portamento from the center of the melody's pitches, the combination is apt to overwhelm us with blissful-sad contingency. $(2013,134)$

CAPTION Fig. 3. 'The words come out of yr mouth but yr eyes say other things.' Kim Gordon/skeleton/drummer, 1990, from Sonic Youth 'Tunic (song for Karen)' video

She never wrote her own lyrics ('No, I don't write.... Nothin' ever came out', she told Country Music: Naglin 1978,217), yet there is a compelling case for reading songs Karen sang as autobiographical. How? For a start, she often sang of aspects of the industry, a metatextual commentary in songs about music, radio, stars, fans. More significantly, even when she took a famous extant lyric, such as the Carpenters' 1977 version of 'Don't cry for me, Argentina' from the musical Evita, one can agree with Los Angeles Times music critic Robert Hilburn, writing shortly after her death: 'the song's lyrics have a chilling quality when considered in light of what we've learned about [Karen] in recent days' (1983, 251). Biographer Randy Schmidt goes further: this song 'was autobiographical when placed in context with the personal struggles she faced over the years' $(2010,174)$. We should acknowledge that many successful pop stars in the destructive economy of their own industry might recognise and agree with the song's observation that 'as for fortune and as for fame / ... they're not the solutions they promised to be' (Carpenters 1977b), but tears and the desperate struggles of a woman with a high public profile, who had transformed her own life, and then her own body, resonated powerfully with Karen Carpenter. As she sang at the end of the song, all we really did have to do was look at her to know that every word was true. Also, of course, regular Carpenters lyricist John Bettis was effectively writing words specifically for her, with her and only her in mind. Because Bettis, Richard and Karen worked so closely together during the 1970s he even found his lyric subjects to be about emotions and experiences the three of them shared: his words, about their lives, scored by Richard, sung by her. It was an intensely closed world which one might call incestuous were that word not already being quite widely used about the brother and sister who sang love songs, seemingly to each other. According to the Coleman band biography, in one song lyric, 'Bettis brilliantly spoke for the inner woman's mood at the time', another was 'a weirdly autobiographical lyric for Karen' $(1994,288,124)$. Once more we see a problematic gender politics in operation, as the words to Karen's 'inner woman's mood' are written by a man. Yet it is her characteristic vocal articulation and interpretation of them on record that we all hear, always; it is 
her singing voice that brings them to life, even when that life expression includes the sublimation of emotion and feeling. Bettis was indeed

regularly writing lyrics that could later be interpreted as sound tracks of her personal life. Karen, too, felt an intuitive response to the messages in John's lyrics, and though it was too tender a subject to debate, they would exchange a knowing remark. (Coleman 1994, 148; emphasis added)

In her 'Open letter to Karen' Kim Gordon (Figure 3) has 'Karen' articulating one of those 'knowing remarks', sort of, as her Karen explains: 'They're not my words.... But I will make the words my own because I have to express myself somehow' (Gordon, n.d.). For the dark side of the Carpenters, 'the underside of El Dorado', as Lott puts it, 'clues exist everywhere in their music' (where else could they? Her anorexia, of course, and youthful death; his drug addiction); various deconstructive readings evidence this. For instance, Lott writes of the 'isolation conveyed in "Close to You," an apparently dreamy evocation of intimacy that is in fact its opposite-“just like me / they long to be / close to you"' (Lott 2008, 227). The screenwriter of a television biopic about Karen found himself re-evaluating the music: "I [used to think] when she sang "I'm on top of the world" she was serious. I never heard the undertones to it, the layers' (quoted in Schmidt 2010, 4). To link word back to music, Morris has identified a very specific 'undertone' in the repeated low $E$ she sings at the end of lines in each verse of 'Top of the world'-'there has been so much of that low E', he observes, explaining:

Thus do sonority and melodic construction make common cause to undermine the song's manifest message.... Our doubts about the perfect world ... have fastened upon the telling sign.

In Morris's view, the low E Karen sings and repeats in falling terminal is the 'telling sign', 'proof that it [the perfect world of which she sings] is not true' (2013, 140; emphasis added).

\section{Other anorexias in popular music: Lena Zavaroni, Richey Edwards}

This is not to suggest that something like anorexia was somehow unspeakable in pop, or only addressable obliquely - as we will see, far from it, today. Possibly riding the wave of anorexia fascination that was created following Carpenter's death in 1983, Lena Zavaroni was a regular on the British chat-show circuit discussing her experience with an openness Karen had been incapable of. Zavaroni was a child star, discovered via a television talent show in 1974. Aged ten, less that five feet tall, she embarked on an international solo pop career packaged as 'The Little Girl with the Big Voice' (see Figure 4), with her first hit single, a cover of the American standard 'Ma! He's making eyes at me.' This is, I have often thought, even back in the seventies, curious material for a prepubescent girl: a song about sexual desire, male seduction and marriage, lighthearted, yes, but hardly appropriate for a ten-year-old. Quite extraordinarily, the words are altered from the original version favoured by other female singers (such as Judy Garland, Eydie Gorme, Teresa Brewer, Annette Funicello). They 
sing, of the seducer's behaviour and awareness of limits: 'Mercy, let his conscience guide him' (Zavaroni 1974a). Zavaroni sings the slightly more easy to deliver and alliterative: 'Mercy, let my conscience guide me'-as though a tenyear-old has or should have a sexual conscience. (He gets his kiss, by the way, and more than one.) Further, to be the 'Little Girl' in pop when you had yet to go through puberty into womanhood is clearly restricting and problematic. In one interview frequently cited in her obituaries and retrospective features about her life and music, she observed:

When they tried to fit me into these costumes, they would talk about my weight. I kept wondering how they expected me to fit into these dresses. I was a plump little girl and I was also developing into a woman. I wanted to be just right for them, but I had to go to all these breakfasts, dinners and lunches. I only became fanatical about not eating when the pressure got too much. (quoted in Thorpe 1999)

Each of these instances, right from the start of her career, highlights at the very least a carelessness by those in the industry who were responsible for looking after her.

Within a few years Zavaroni became also an experienced television presenter, fronting her own music and variety shows on both main British channels of the time. So she was comfortable on camera, as presenter, performer, or guest. On one 1985 chat show, she talked about her showbiz return, with a stark opening statement, followed by a therapy-style second-person objective observation, one that places her musical practice at the centre of her strategy or fantasy: 'To be truthful, I never thought I would come back, I really had terrible doubts. Until you get over a thing like that, because it's part of your life at that time,... that's when you start looking at things you want out of your life. I decided that the thing that's going to get me back hopefully to full standard again is singing' (in Alexander 2000; emphasis added). Did Zavaroni really believe that, that singing would, even could, be her cure? Or was it self-delusion, or a plea to the television audience to remember that a singer is what she had been? At the height of her child stardom she was regularly performing on American television (and indeed at the White House for President Ford on one occasion). Jerry Lewis

introduced her as a turn on one of his telethons: 'Wait till you hear the voice that comes out of this kid. If you close your eyes you might think she's Judy Garland' (Zavaroni 1974b). Sadly there would become some truth in that.

CAPTION Fig. 4. 'The little girl with the big voice.' Lena Zavaroni, 30 March 1974. At Madurodam miniature town, Netherlands

A decade or so after Zavaroni's regular chat show appearances discussing anorexia came a notable piece of popular music, words written by a man, sung by another man, that stands as a stark effort at capturing the subjective experience of an eating disorder. The lyrics of '4st 7lbs' by the Manic Street Preachers were written by Richey Edwards, the band's guitarist and art stylist, one could say. At the time Edwards was struggling with anorexia and depression, had been selfmutliating on stage, was in and out of psychiatric hospitals, and within a few 
months would disappear, presumed suicide. The lyrics chart, in the first person, the weight loss of a young woman, from 6 st to 5st 2lbs to finally 4st 7lbs (63 pounds), like the poetic diary of an anorexic. Karin Eli describes the song and its narrative trajectory: it is sung in body parts and numbers. Its protagonist, a nameless adolescent girl, perpetually looks downward, fixing her gaze on her breasts, her ribs, her feet, the scale. She counts herself down, lying in wait for the non-launch' (Eli 2012, 1).

'4st 7lbs' is sung by the band's male rock vocalist James Dean Bradfield, in a challenging act of phrasing and delivery. The front cover of the album it appears on, The Holy Bible (1994), shows a triptych painting of an obese woman, dressed only in underwear, fleshy female folds signalling for the listener the concern within, pointing to the key song. Among what seem to me overblown rock songs about the Holocaust and torture on this widely acclaimed album is the most personal, therefore effective, one, which Martin Power describes in his history of the band as containing Richey Edwards's 'most profoundly moving lyric' (2010). The song opens with a distorted guitar riff and a sample of a young woman, Caraline Neville-Lister, talking about her anorexia, taken from a contemporary BBC television documentary: 'I eat too much to die, not enough to stay alive' (Llewellyn-Jones 1994). In the lyric, there are relatively few rhymes, and many of the lines do not scan the musical structure, though there is a certain verse-chorus pattern imposed by the music. It is a non-fit, a study in awkwardness and dysfunction, with a tempo change, ritenuto, towards the end to-well, what? Suggest the wasting through the musical slowness? Try to slow down the wasting's fatal progression? (We should ask how far the lyricist's subsequent suicide clouds or complicates his character's eating disorder. It is in the manner of the rock and roll suicide-a profoundly impoverishing cultural phenomenon, in my older man's and fan's strongly-held view-that the ending of the song, of her story, is magnified by his own ending.) The picture drawn is harrowing, of course, in describing what seems to be the girl's deluded vanity and ready acceptance of damage, but also illuminating and even witty.

So gorgeous sunk to six stone ...

Stomach collapsed at five

Lift up my skirt my sex is gone ...

My vision's getting blurred

But I can see my ribs.... (Manic Street Preachers 1994)

The rock star male and his anorexic female persona merge when we see the performative demands and the sheer disdain for the ordinary audience, who are 'fat scum'.

This discipline's so rare so please applaud Just look at the fat scum who pamper me so. (Manic Street Preachers 1994)

Yet Edwards is the guitarist, not the singer of the band. While he stands thin on stage or screen authenticating his own lyrics, making them and him '4 REAL' (the words he cut on his arm after an early concert in 1991 before a music journalist 
and a photographer) there is a double act of distantiation. First, the use of the girl as lyrical persona, and second, the fact that his words of intense personal expression are (always) sung by someone else, the not-quite-so-thin lead singer Bradfield. (A New Musical Express feature about the band in 1992 described Bradfield as the Marlon Brando-era Stanley Kowalski to Edwards's Blanche Dubois from Tennessee Williams's A Streetcar Named Desire: Bailie 1992.) Arguably Edwards is feminised in his own lyric and masculinised by his band's singer. Today, a little more burly in middle age perhaps, Bradfield still sings the song in the live set; it survives and is not diminished. '4st 7lbs', written and sung by two men, performed by one of them across decades, helps us see another gendered perspective on eating disorders.

\section{Conclusion: pro-ana music and media}

I know I ask perfection of a quite imperfect world. Carpenters, 'I need to be in love' (1976)

In the 1990s Richey performed anorexia, as part of some kind of rock aesthetic of self-destruction, and wrote the lyrics of a powerful, extraordinary song about it. In the 1980s Lena talked of anorexia, seemingly on any television chat show that would have her as a guest, as she tried to revive her career, but she never sang of it. In the 1970s Karen, the pop groundbreaker, did not even like to say the words 'anorexia nervosa', not even (or especially) after a full year's therapy in New York to try to deal with it. No 'waif warrior' (Katzman 2009, xvii), seemingly, our Karen. She never sang directly of it, of course, and yet it seems everywhere in the Carpenters music, from the technologised perfection of the sound on record to her gasp-inducing body unhidden by drums for concert audiences, from her wide- or empty-eyed, smiling denial to the often banal pop lyrics that somehow always suggested more and worse-'In my own time nobody knew the pain I was going through' (Carpenters 1975) - to the void voice that was so full.

There is today a thriving online subculture in pro-ana songs, images, websites, social media, youtube channels such as anamiamusic. The songs that are on these platforms are usually self-written, commonly feature young female voices, breathy vocal recording, high pitch - sonic signifiers of sensitivity-often sparsely accompanied by acoustic guitar or piano, lyrically-focused. Others included are classic rock or grunge songs with male singers whose lyrics articulate or are understood as referencing the (angry) experience of eating disorders. There are some pop hits. Nowadays, it seems, the teenager's bedroom mirror, once a reflective screen for practising guitar poses, frames alternate pop corporealities, while the essential mobile phone, its music, screen and camera, instantly accesses every triggering song ever and you can kik your ana buddy at the same time. Even in anorexia's treatment, music signifies: the use of songwriting as a preferred mode of music therapy for adolescents with eating disorders confirms their 'already existing relationship with music and their identification with particular songs or artists who resonated with their life experience' (McFerran et al 2006, 402). So, perhaps Lena was right on that 1985 chat show: singing songs could help lead back to 'full standard'. 
(It is worth noting that in my survey I found fewer mentions of Karen Carpenter than I expected on comment boards and chat groups from these mostly younger web mistresses and contributors. In this context at least she does not figure in what Morris describes variously as 'a martyrology' or 'canonization' $(2013,118,119)$. I do not think her absence is because of the historical nature of Carpenters music-after all, artists and songs like the Monkees' '99 pounds' (recorded 1967, released 1970), Elton John's 'Tiny dancer' or the Kinks' 'Skin and bone' (both 1971) are all mentioned in various contexts, therefore speak to the new, younger audiences. It may be because lyrically there is no obvious mention of eating disorders in the Carpenters' repertoire, not even in song titles, or the music's smoothness is not heard as containing identifiable sonic signifiers of suffering, pain or anger, or the young people that mostly construct, post to and read such sites do not actually want to make dead (female) heroes, say.)

What follows is a set of lyrics from songs about anorexia or featuring on anamia websites. These are wordy snapshots, forming a nosological cento, sort of. In reading (aloud), one may pause, after each. What is the critical or theoretical imperative, here? I can at least say this: in their creativity such lyrics and readings offer ... something, whether that is positive (the articulation or understanding of anorexia) or negative (triggering), or a dis/comforting mix of both. Thinking of creativity, it is well worth acknowledging Karin Eli's key observation in her short reading of that Manics song: although '4st 71bs' 'is bookended by death,' she writes, 'I still find that the song's profoundest insight is about survival. Edwards eloquently captured eating disorder as an immersive, lived process' (Eli 2012, 2; emphases added). While anorexia may (does) remain puzzling, here are some of the answers of anorexics themselves, as popular music fans and performers, which are alternatively powerful and profound, sobering and moving, banal and domestic, funny and frightening.

Perfection is a disease of nation. Please die, Ana. Hiding in my baggy jeans. Society made me fat. Perfect weight, 88. All worn out and nothing fits. I have you to save my day. Skeleton you are my friend. You're so fucking special, I wish I was special. Ana wrecks your life like an anorexia life. When may we leave the table? I'm Mrs She's too big now she's too thin. I told you to be balanced. You're coming undone. If I swallow anything evil put your finger down my throat. Thin, where the hell have you been? Mother tries to choke me with roast beef. Don't make noise you'll break your legs. Underweight goddess. Hey mom, look, I'm up here, I finally made it. Anorexia will cut your life much shorter (Shut the fuck up). I hear you're losing weight again. Hi my name is Ana and I'm here to save you-very smart of you to call me. Mirror mirror on my wall. Wants to look like a star, but she takes it too far.

The final rhyming couplet is taken from Canadian singer-songwriter Rachel Ferguson's 'Never good enough' (Ferguson 2006), a song that features regularly on pro-ana, thinspiration and general ED sites and lists. It captures something of the relationship between the constructed and mediated expectations of pop culture and the fantasy or desire of the young (female) fan or wannabe, though 
again we should bear in mind Burns's warning about too readily accepting 'the inscriptive power of cultural images of thinness' $(2009,124)$. I hope this article has shown ways in which one influential creative cultural sector, the popular music industry, is capable of producing and reproducing disastrous lives for its stars, or at least of demanding of their bodies something extraordinary and then being incapable of or uninterested in helping them negotiate let alone recover from their willed transformation. Lott views this as the 'culture-industry death drive' $(2008,231)$, I have myself written of the 'destructive economy' of pop (2013), of how it can function as a disabling culture, while Holmes sees the contemporary media landscape as being pervasively populated by the figure of the 'female celebrity "train wreck"' $(2015,814)$. I have aimed to deepen our understanding of the operations and processes of the industry for some of its own workers, their health and survival, and for pop fans. I have also sought to widen critical discussion on a specific culture of anorexia, as we might put it.

\section{Acknowledgements}

I would like to thank a reviewer of Shakin' All Over: Popular Music and Disability for asking in her review something like, Why no Karen Carpenter?, and setting me off on a journey. That was Jessica A. Holmes, in Ethnomusicology Review. Good question. Also I thank my University of East Anglia colleague Su Holmes for initial critical discussions and for sharing some resources, as well as for a sharp critical reading of a draft (errors remain mine), my musician friend Joey Herzfeld for being interested enough in the music of the Carpenters to point me to some of the lesser-known repertoire, and the members of the International Association for the Study of Popular Music discussion list for responding so fulsomely to my query about drummer/lead-singers. Finally I do want to acknowledge with gratitude the work of the two anonymous readers during the journal review process: their sensitive and incisive comments have, I hope, helped the critical focus.

Image credits. Figure 1: Collection RN-WHPO: Nixon White House Photographs. NARA-194770. Public domain. Figures 2 and 3: Fair use. Figure 4: 'Lena Zavaroni 927-0962' by Nationaal Archief, Den Haag, Rijksfotoarchief-Fotocollectie Algemeen Nederlands Fotopersbureau (ANEFO), 1945-1989. CC BY 4.0.

\section{References}

Alexander, John, dir. 2000. The Real Lena Zavaroni. Channel Four Television. Broadcast 23 February 2000, part of the Trouble With Food season of programmes.

Anderson, Patrick. 2010. So Much Wasted: Hunger, Performance, and the Morbidity of Resistance. Durham NC: Duke University Press.

Anon. 1975. 'Concert review: Riviera, Las Vegas, August 24, 1975.' Variety (September 3). In Schmidt 2012, 135-136.

Bailie, Stuart. 1992. 'Manic Street Preachers interview.' New Musical Express. Reprinted online 2015. http://www.nme.com/features/manic-street- 
preachers-interview-read-a-classic-nme-interview-with-the-band-frommay-1992-on-the-emp-757238. Accessed June 162017.

Bangs, Lester. 1971. 'The Carpenters and the creeps.' Rolling Stone (March 4). In Schmidt 2012, 17-21.

Brumberg, Joan Jacobs. 2000. Fasting Girls: The History of Anorexia Nervosa. First published 1988. New York: Vintage.

Burns, Maree. 2009. 'Bodies as (im)material: bulimia and body image discourse.' In Helen Malson and Maree Burns, eds. Critical Feminist Approaches to Eating Dis/Orders. London: Routledge, 124-134.

Carpenter, Karen. 1996. 'Last one singin' the blues.' Recorded 1979/1980. On Karen Carpenter. A\&M Records.

Carpenter, Richard. 1983. Interview on Good Morning America. November 2. http://www.youtube.com/watch?v=B9XGUg0ef28. Accessed 6 August 2016.

Carpenters. 1972. 'Top of the world.' On A Song for You. A\&M Records.

Carpenters. 1975. 'Only yesterday.' On Horizon. A\&M Records.

Carpenters 1976. 'I need to be in love.' On A Kind of Hush. A\&M Records.

Carpenters. 1977a. 'Two sides.' On Passage. A\&M Records.

Carpenters. 1977b. 'Don't cry for me, Argentina.' On Passage. A\&M Records.

Coleman, Ray. 1975. 'Carpenters-good, clean, all-American aggro!' Melody Maker (November 8). In Schmidt 2012, 145-174.

Coleman, Ray. 1994. The Carpenters: The Untold Story: An Authorized Biography. London: Boxtree.

Eli, Karin. 2012. '4st 7lbs': Eating Disorders, Between Horror and Survival. UBVO Opinion Paper \#03. Oxford: Unit for Biocultural Variation and Obesity.

Farrell, Amy Erdman. 2011. Fat Shame: Stigma and the Fat Body in American Culture. New York: New York University Press.

Ferguson, Rachel. 2006 (?). 'Never good enough.' http://www.youtube.com/watch?v=bgeLislRCko Accessed 14 March 2017.

Garner, David, and Paul E. Garfinkel. 1980. 'Socio-cultural factors in the development of anorexia nervosa.' Psychological Medicine 10: 647-656.

Gordon, Kim. No date. 'Open letter to Karen.' Extracted at http://dangerousminds.net/comments/kim gordons open letter to kare n carpenter Accessed 16 April 2016.

Holmes, Su. 2015. "Little Lena's a big girl now": Lena Zavaroni and the anorexic star.' Feminist Media Studies 15(5): 813-828.

Jarman-Ivens, Freya. 2007. 'You're not really t/here: authorship, nostalgia \& the absent "Superstar."' Popular Musicology Online, issue 5.

http://www.popular-musicology-online.com/issues/05/jarman-ivens01.html Accessed 5 August 2015.

Jarman-Ivens, Freya. 2011. Queer Voices: Technologies, Vocalities, and the Musical Flaw. Basingstoke: Palgrave Macmillan.

Katzman, Melanie A. 2009. 'Foreword.' In Helen Malson and Maree Burns, eds. Critical Feminist Approaches to Eating Dis/Orders. London: Routledge, xvii-xx.

'List of best-selling music artists.' 2017. Wikipedia. http://en.wikipedia.org/wiki/List of best-selling music artists. Accessed 13 February 2017. 
Llewellyn-Jones, Jeremy, dir. 1994. Caraline's Story: A Young Anorexic's Final Months. BBC Television. Broadcast 11 April 1994, in the Forty Minutes documentary series.

Lott, Erik. 2008. 'Perfect is dead: Karen Carpenter, Theodor Adorno, and the radio; or, if hooks could kill.' Criticism 50(2): 219-234.

Lubet, Alex. 2011. Music, Disability, and Society. Philadelphia: Temple University Press.

Malson, Helen M., and Jane M. Ussher. 1997. 'Beyond this mortal coil: femininity, death and discursive constructions of the anorexic body.' Mortality: Promoting the Interdisciplinary Study of Death and Dying 2(1): 43-61.

Malson, Helen. 1998. The Thin Woman: Feminism, Post-Structuralism, and the Social Psychology of Anorexia Nervosa. London: Routledge.

Manic Street Preachers. 1994. '4st 7lbs.' On The Holy Bible. Epic Records.

Marcus, Greil. 1991. Dead Elvis: A Chronicle of a Cultural Obsession. Harmondsworth: Penguin, 1992.

McFerran, Katrina, Felicity Baker, George C. Patton, and Susan M. Walker. 2006. 'A retrospective lyrical analysis of songs written by adolescents with anorexia nervosa.' European Eating Disorders Review 14: 397-403.

McKay, George. 2009. "'Crippled with nerves": popular music and polio, with particular reference to Ian Dury.' Popular Music 28(3): 341-365.

McKay, George. 2013. Shakin' All Over: Popular Music and Disability. Ann Arbor: Michigan University Press.

Morris, Mitchell. 2013. The Persistence of Sentiment: Display and Feeling in Popular Music of the 1970s. Berkeley: University of California Press.

Naglin, Nancy. 1978. 'The Carpenters go country?' Country Music (August). In Schmidt 2012, 215-219.

Nationwide. 1981. BBC Television current affairs programme. Interview by Sue Lawley with the Carpenters, including out-takes. 22 October 1981. http://www.youtube.com/watch?v=hs50xc3Qn40 Accessed 22 January 2017.

Pawlowski, Cheryl, and LeAnna DeAngelo. 2016. 'Anorexia nervosa.' Magill's Medical Guide (Online Edition) (January 2016). Accessed 15 October 2016.

Power, Martin. 2010. Nailed to History: The Story of Manic Street Preachers. London: Omnibus.

Rose, Ethan. 2015. '15 musicians who have suffered from eating disorders.' Rant Hollywood website (28 February). http://www.ranthollywood.com/2015/02/28/15-musicians-who-havesuffered-from-eating-disorders/. Accessed 23 November 2016.

Saukko, Paula. 2006. 'Rereading media and eating disorders: Karen Carpenter, Princess Diana, and the healthy female self.' Critical Studies in Media Communication 23(2): 152-169.

Schmidt, Randy L. 2010. Little Girl Blue: The Life of Karen Carpenter. London: Omnibus.

Schmidt, Randy L., ed. 2012. Yesterday Once More: The Carpenters Reader. Rev. edn. Chicago: Chicago Review Press.

Shell, Marc. 2005. Polio and its Aftermath: The Paralysis of Culture. Cambridge: Harvard University Press.

Smith, Angela. 2014. Women Drummers: A History from Rock and Jazz to Blues and Country. New York: Rowman and Littlefield. 
Smucker, Tom. 1975. 'The Carpenters: forbidden fruit.' Village Voice (June 2). In Schmidt 2012, 85-87.

Sonic Youth. 1990. 'Tunic (song for Karen).' On Goo. DGC Records.

Tiggemann, Marika, and Amy Slater. 2004. 'Thin ideals in music television: a source of social comparison and body dissatisfaction.' International Journal of Eating Disorders 35(1): 48-58.

Thomson, Rosemarie Garland. 1997. Extraordinary Bodies: Figuring Physical Disability in American Culture and Literature. New York: Columbia University Press.

Thorpe, Vanessa. 1999. 'Anorexia snuffs out the child pop star who never grew up.' The Observer (3 October). http://www.theguardian.com/uk/1999/oct/03/vanessathorpe.theobser ver. Accessed June 162017.

Vargesson, Neil. 2015. 'Thalidomide-induced teratogenesis: history and mechanisms.' Birth Defects Research Part C, 105: 140-156.

Various artists. 1994. If I Were A Carpenter. A\&M Records.

Vernallis, Carol. 2013. Unruly Media: YouTube, Music Video and the New Digital Cinema. Oxford: Oxford University Press.

Warwick, Jacqueline and Allison Adrian, eds. 2016. Voicing Girlhood in Popular Music: Performance, Authority, Authenticity. Abingdon: Routledge.

Zavaroni, Lena. 1974a. 'Ma! (He's making eyes at me)' / 'Rock-a-bye your baby with a Dixie melody.' Philips Records.

Zavaroni, Lena. 1974b. 'Ma! (He's making eyes at me).' On Jerry Lewis, Muscular Dystrophy telethon, September 1974. http://www.youtube.com/watch?v=PWe7gImXAoE. Accessed 10 July 2017. 